\title{
Influence of online transparency on efficiency. Analysis of spanish NGDOs
}

\author{
Víctor Martín Pérez \\ Natalia Martín Cruz
}

ABSTRACT: This study examines (a) whether nongovernmental development organizations (NGDOs) disseminate relevant information for their stakeholders through their web pages, information that after being reviewed and evaluated by external organizations such as the Spanish Coordinator of Development NGO or Lealtad Foundation, allowed these NGDOs to obtain a seal of transparency and (b) whether their level of transparency influences efficiency. To determine online transparency, web pages of seal-approved NGDOs were reviewed to assess the availability of relevant information. This paper uses data envelopment analysis to assess the efficiency using an input orientation. To determine the influence of online transparency on efficiency, an ordinary least squares regression was used. Results show that while increased transparency has a significant effect on efficiency, the level of information disclosure of NGDOs through their web pages has considerable room for improvement. Improved transparency leads to best practices and increased competition in obtaining financing and support from society. To improve transparency in the nonprofit sector, external organizations have created a series of seals to certify that an organization complies with the basic principles of transparency. In addition, new technologies make it easier for organizations to disseminate information quickly and economically. This article contributes to the literature regarding web use of NGDOs to disclose relevant information and analyzing the influence of online transparency on organizational efficiency.

KEYWORDS: Transparency, efficiency, web page, information disclosure, data envelopment analysis, nongovernmental development organizations.

ECONLIT DESCRIPTORS: C14, C29, D64, D83, L31, M41.

How to cite this article: MARTíN, V. \& MARTíN, N. (2020): "Influence of online transparency on efficiency. Analysis of spanish NGDOs", CIRIEC-España, Revista de Economía Pública, Social y Cooperativa, 99, 5-35. DOI: 107203/CIRIEC-E.99.15382.

Correspondence: Víctor Martín Pérez, vmartin@eco.uva.es, ORCID: 0000-0002-0532-9425; Natalia Martín Cruz, ORCID: 0000-0002-5687-4060.

Departamento de Organización de Empresas y C.I.M., Facultad de CC. EE. y Empresariales Universidad de Valladolid. 


\section{RESUMEN AMPLIO}

\section{Influencia de la transparencia online sobre la eficiencia. Análisis de las ONGD españolas}

\section{Objetivos}

La reciente crisis económica unida a las irregularidades y fraudes que han tenido lugar en los últimos años en algunas de las más conocidas ONG del panorama nacional e internacional han conllevado una mayor demanda de rendición de cuentas por parte de las organizaciones no lucrativas, sobre todo, las ONGD debido a su creciente importancia como agentes canalizadores de la ayuda oficial al desarrollo. La rendición de cuentas se ha convertido en una de las principales preocupaciones de estas organizaciones, destacando la necesidad de mejorar su transparencia para salvaguardar su reputación y legitimidad (Carvalho et al., 2017).

El sector no lucrativo ha desarrollado una amplia variedad de sistemas de auto-regulación así como herramientas de certificación y acreditación (Gugerty, 2009). La principal diferencia entre estas iniciativas es si están basadas en mecanismos de control internos (aplicados internamente por la propia organización, como, por ejemplo, la divulgación voluntaria de información) o en mecanismos de control externos aplicados por entidades independientes, como las certificaciones de transparencia y buen gobierno (Becker, 2018).

Las diferentes certificaciones y sellos emitidos por instituciones independientes para demostrar la transparencia de las organizaciones no lucrativas son consecuencia de la ausencia de un sistema de certificación oficial a nivel de la Unión Europea (Becker, 2018). Estas certificaciones son consideradas en el sector como una forma de rendición de cuentas muy exigente (Gugerty, 2009; Willems et al., 2017) puesto que una entidad externa independiente revisa la calidad de los procesos y programas de las organizaciones (Slatten et al., 2011).

La divulgación voluntaria de información permite dar respuesta a las necesidades informativas de los stakeholders y facilita sus procesos de toma de decisiones (Cabedo et al., 2017). No obstante, la información financiera que había venido siendo la que tradicionalmente se ofrecía ya no es suficiente (Saraite et al., 2020), los diferentes stakeholders cada vez más demandan información no financiera, relacionada con las actividades, la gobernanza o los proyectos (Montesinos and Bruna, 2019). Es aquí donde las páginas web cobran importancia al permitir difundir información actualizada, con un coste reducido y un fácil acceso (López, Torres y Bellostas, 2019). La transparencia online incluye la divulgación voluntaria por parte de las organizaciones no lucrativas de información fiable, precisa oportuna y verificable, tanto financiera como no financiera (Lee y Blovin, 2017). De este modo sus 
stakeholders pueden conocer lo que la organización hace, cómo lo hace (Farwell, Shies y Handy, 2019) y en qué medida es eficiente en lo que hace (Lee y Blovin, 2017).

En un entorno de competencia creciente, ser eficiente es crucial para lograr la misión de la organización al tiempo que se refuerza el apoyo de los principales donantes. La eficiencia en el ámbito no lucrativo no tiene tanto que ver con la reducción de costes como con la maximización de los servicios que la organización presta con los recursos limitados de que dispone (Coupet y Berret, 2019). La eficiencia calculada con el análisis envolvente de datos (DEA) permite medir el grado en el que las organizaciones no lucrativas son capaces de transformar inputs (lo que gastan) en outputs (bienes y servicios producidos para la comunidad). Esta medida, basada en datos objetivos, evita el riesgo del sesgo de conveniencia inherente en las valoraciones de desempeño realizadas por las propias organizaciones no lucrativas (Rey, Sanzo y Álvarez, 2018).

Con estos antecedentes, este trabajo analiza: a) en qué medida un grupo de ONGD divulgan información relevante para sus stakeholders a través de sus páginas web, información que les ha permitido obtener un sello de transparencia concedido por la Coordinadora de ONG de desarrollo y/o por Fundación Lealtad, y b) si el nivel de eficiencia logrado por las ONGD, calculado por medio del análisis DEA, viene influido por su nivel de transparencia online.

\section{Metodología}

Se realizó un análisis de contenido de las páginas web de cada una de las 114 ONGD que contaban con el sello de transparencia concedido bien por la Coordinadora de ONG de desarrollo, bien por Fundación Lealtad. Los estudios basados en el análisis de contenido de las páginas web han sido ampliamente utilizados para valorar la cantidad de información revelada por las organizaciones no lucrativas (Gálvez et al., 2012; Andrades et al., 2019; Benito et al., 2019; Pina y Torres, 2019). Este método valora la presencia o ausencia de ciertos ítems, asignando el valor 1 cuando la información relativa a un ítem es divulgada y el valor 0 en caso contrario. De este modo se obtiene un indicador numérico de la información divulgada, conocido como índice de transparencia (Ramírez et al., 2019; Benito et al., 2019).

Una vez realizado el análisis de contenido, se calculó la eficiencia aplicando el análisis DEA, una metodología especialmente adecuada para las organizaciones no lucrativas que no buscan obtener un beneficio económico sino generar valor social. La información requerida para aplicar el DEA se obtuvo de las memorias anuales de cada una de las organizaciones que integran la muestra.

Finalmente, se llevó a cabo un análisis de regresión por mínimos cuadrados ordinarios para valorar la influencia de la transparencia online sobre la eficiencia, tomando en consideración el efecto de varios factores organizativos. La información relacionada con los factores organizativos fue obtenida a partir de las páginas web así como de las memorias anuales de cada una de las organizaciones. 


\section{Resultados}

En general, las páginas web tienen bastante recorrido de mejora por lo que respecta a la información que divulgan. El índice de transparencia global alcanza un valor del $53.2 \%$, o lo que es lo mismo, las ONGD que cuentan con un sello de transparencia emitido por instituciones externas, divulgan poco más de la mitad de la información que los stakeholders consideran relevante para una adecuada rendición de cuentas, En cuanto a la información divulgada, se observan importantes diferencias, así la transparencia relacionada con las actividades de la organización alcanza el valor más elevado mientras que la transparencia económico-financiera ofrece el valor más bajo. Este resultado es sorprendente porque, tradicionalmente, las organizaciones no lucrativas se han centrado en la rendición de cuentas hacia los grandes donantes, más interesados en la información económica y financiera.

La eficiencia media de las organizaciones de la muestra es de 0.81 , valor considerablemente elevado por comparación con los valores medios obtenidos en estudios previos en el sector no lucrativo. Finalmente, el análisis de regresión muestra que la transparencia online influye positiva y significativamente sobre el nivel de eficiencia. En resumen, los resultados indican que si bien una mayor transparencia online influye de forma significativa sobre la eficiencia, los niveles de divulgación de información de las ONGD a través de sus páginas web son manifiestamente mejorables.

\section{Conclusiones}

Actualmente, se demanda una creciente transparencia y rendición de cuentas de las organizaciones no lucrativas, especialmente cuando hay poca información disponible para valorar el desempeño (Santos, Laureano y Moro, 2020) y la eficiencia de la organización. Los directivos de las entidades no lucrativas deben ser capaces de aprovechar el potencial de las páginas web para, con unos costes reducidos, aumentar los niveles de transparencia mejorando con ellos la legitimidad de sus organizaciones y la confianza entre los stakeholders. Esta confianza puede ser muy volátil de ahí la importancia de fomentar y mejorar la transparencia para poder generar una mayor confianza y compromiso de los stakeholders. Como plantean Sanzo et al. (2017), la transparencia online voluntaria es una herramienta ideal para poder rendir cuentas a múltiples stakeholders.

No solamente se demanda más transparencia sobre las actividades y prácticas de gestión y de gobernanza de las organizaciones no lucrativas, sino también sobre el rendimiento y eficiencia de las mismas. Dar respuesta a esta demanda requiere disponer de medidas de eficiencia objetivas, precisas y fiables que permitan discriminar entre las organizaciones más y menos eficientes. La utilización del DEA, al considerar múltiples dimensiones del funcionamiento organizativo, aporta una visión más enriquecedora del fenómeno, y resulta sumamente útil para los gestores ya que permite realizar un análisis más exhaustivo que determine cuáles son las verdaderas causas que explican por qué unas organizaciones logran un mejor aprovechamiento de sus recursos, de forma que las mejores prácticas 
del sector puedan ser adoptadas y replicadas por aquéllas organizaciones que se encuentran en peor situación.

Una mayor transparencia, al mejorar la información que se tiene de las organizaciones, incrementará la competencia para obtener financiación y apoyo de la sociedad, motivando a las organizaciones a aplicar mejores prácticas de gestión para mejorar su eficiencia.

\section{Contribución}

Para mejorar la transparencia en el sector no lucrativo, entidades externas han desarrollado una serie de sellos para certificar que una organización verifica los principios básicos de transparencia. Además, las nuevas tecnologías posibilitan que las organizaciones divulguen información de una forma rápida y económica. Este trabajo contribuye a la literatura analizando la divulgación de información relevante que las ONGD llevan a cabo a través de sus páginas web. Su principal valor añadido reside en la demostración empírica de la relación entre transparencia online y eficiencia en el contexto de las organizaciones no lucrativas que operan en el sector de la cooperación al desarrollo.

PALABRAS CLAVE: Transparencia, eficiencia, página web, divulgación de información, análisis envolvente de datos, organizaciones no gubernamentales para el desarrollo. 


\section{Introduction}

The development sector has experienced substantial growth in recent years, and nongovernmental development organizations (NGDOs) have emerged as a fundamental actor (Martín and Martín, 2017a). Although they channel a large portion of official development aid, instances of fraud and mismanagement have recently marred the reputation of some of the world's most well-known NGDOs (e.g., Anesvad, Intervida, l'Arche de Zoé, United Way of America, Cancer Fund of America, among others). As a result, both the governments and society that support these organizations have called for greater transparency (Gálvez et al., 2012; Rocha et al., 2015; Santos et al., 2020) and efficiency (Martín and Martín, 2017a).

Given their growing importance and recognition of their work, NGDOs face an increasing need be transparent to generate trust, ensure the support of their main stakeholders (Gálvez et al., 2014), legitimize themselves in society (Carvalho et al., 2017), and create the conditions that favor their sustainability (Vernis et al., 2004). As a result, private organizations ${ }^{1}$ offer external control mechanisms and issue transparency and good governance certifications-in Spain the most remarkable are Lealtad Foundation (Transparency and Good Practices Guide) and the Spanish Development NGO Coordinator (Transparency and Good Governance Tool). In addition, NGDOs can use internal control mechanisms. For example, at minimal cost, organizations can disclose to their stakeholders, in real time and with frequent updates, relevant information via their web site, thereby increasing their accountability.

In addition to being accountable and transparent, NGDOs must also be efficient. Although the NGDO sector has a fundamental concern for effectiveness - that is, successfully achieving its objectives-given scarce resources, efficiency is closely linked with effectiveness (Duflo and Kremer, 2003; Banerjee, 2009). Being more efficient enables an NGDO to carry out more actions with the same amount of resources, allowing it not only to multiply the effect of the resources allocated to development aid but also to reduce the pressure on donor agencies and institutions. In this sense, the tendency of governments to outsource the implementation of official development aid makes efficiency an imperative for NGDOs (Martín and Martín, 2017a).

Although theoretical literature has recognized the importance of transparency and online information disclosure in the nonprofit sector (Paton and Foot, 2000; McGann and Johnstone, 2006; Bies, 2010; Burger y Owens, 2010; Gandía, 2011; Murtaza, 2012) there is no significant empirical research

\footnotetext{
1.- International examples are European Foundation Center (Principles of Good Practice), the Independent Sector (Principles of Good Governance and Ethical Practice: A guide for foundations and charities), the One World Trust (Global Accountability Report) or the United States Council on Foundations (Stewardship Principles and Practices for Independent Foundations).
} 
(De França et al., 2010; Rocha et al., 2014; Gálvez et al., 2016) evaluating its influence on the nonprofit organizations' level of efficiency, so there is a research gap to fill.

The goal of this study is twofold. First, we investigate the extent to which a group of Spanish NGDOs disseminate relevant information for their stakeholders through their web pages ${ }^{2}$. That is, do they make publicly available relevant information on organizational, economic, financial aspects and activities, as well as functioning and governance. In doing so, we performed a content analysis of the websites of sample organizations. Second, we investigate whether a NGDO's level of online transparency influences its level of efficiency. We calculate efficiency using a data envelopment analysis (DEA). This method is particularly effectively in assessing the efficiency of NGDOs because it allows us to consider the multiple dimensions of objective and the resources used while also taking into account characteristics unique to each NGDO. After estimating efficiency, an ordinary least squares regression was used to analyze the influence of online transparency on efficiency including some contextual and organizational variables.

The remainder of the paper is organized as follows. Section 2 presents the theoretical framework and the research hypothesis. Section 3 explains the sample, variables and method of analysis. Section 4 presents the results and main findings of the empirical analysis. Finally, Section 5 provides conclusions and discusses the main limitations of the study.

\section{Transparency and Efficiency}

Literature on information transparency has focused mainly on donors and sponsors (Ebrahim, 2003, 2005; Christensen and Ebrahim, 2006; O'Dwyer and Unerman, 2007, 2008) to the detriment of recipients of aid-that is, those to whom it is directed or on whose behalf it is spent (McGee, 2013). This emphasis is largely motivated by the importance of maintaining funding in an increasingly competitive environment: A growing number of nonprofit organizations compete for a declining number of resources (Schmitiz et al., 2012; Eckerd and Moulton, 2011; Ebrahim, 2005; Phillips, 2013).

Although the literature has called to reduce informational asymmetries between small and large donors (Keating and Frumkin, 2003), traditionally, large donors and especially public donors have had access to much more complete information about NGDOs due to the control related to size of their donations. This greater transparency also mitigates information asymmetries between the principal and the agent (Gonedes, 1978; Leftwich et al., 1981) and thus reduces the power of agents by making

2.- This information, after being reviewed and evaluated by external organizations such as the Spanish Coordinator of Development NGO or Lealtad Foundation, allowed these NGDOs to obtain a seal of transparency. 
more information available to the principals. Therefore, the delivery processes are closer to the principals' preferences (Christensen et al., 2010) and reduce the conflicts of interest and mismanagement of resources (Szper and Prakash, 2011), because they are a powerful signaling mechanism. In fact, transparency is positive not only for donors and funders but also for any stakeholder in an organization (Burger and Owens, 2010) because it facilitates the external control of the organization (Gugerty, 2009; Burger and Owens, 2010), which improves performance (Murtaza, 2012) and efficiency (Benjamin, 2010).

Despite the previously mentioned advantages, in the nongovernmental organization (NGO) sector in general and in the NGDO sector in particular, the costs related to the preparation and dissemination of information is of great concern. These costs increase administrative expenses and can negatively influence donors because they reduce resources available for the realization of projects and impair efficiency. Although increasing transparency generates costs, Chisholm (1995, p. 154) suggests, "Measures that increase the amount of information available to individuals who make decisions about which organizations support, contribute or are part of them, they can only improve the important mediating role of the nonprofit sector between the individual and society". Thus, the dissemination of information has inherent value to the nonprofit sector and is integral to the mission of each organization. In addition, transparency costs have significantly declined due to the ability of NGDOs to share information via their web sites. Web pages allow NGDOs to disclose information at a very low cost in real time, with frequent updates. Thus, Internet technologies have made it possible to overcome the primary obstacle to increased transparency by significantly reducing the associated costs.

Given this discussion and based on De França et al. (2010), Rocha et al. (2014) and Gálvez et al. (2016), we posit that increased transparency improves sponsors' ability to understand the extent to which NGDOs apply best practices and allows NGDOs to be more efficient in fundraising and in achieving their validity to society. We therefore state the following hypothesis:

H1: The level of an NGDO's online transparency is positively related to its level of efficiency.

\subsection{Mechanisms to improve transparency}

In Spain, despite the importance of transparency, both to generate trust with stakeholders and to legitimize the nonprofit organizations themselves, no governmental regulations (Gandía, 2011) or specific international standards (Becker, 2018) exist that dictate transparency for nonprofit organizations. A lack of external controls cast doubts about the sector's legitimacy, and these doubts can have serious consequences in terms of fundraising and effectiveness.

Aware of the need for external standards, the Spanish nonprofit sector has attempted to improve its transparency and accountability via self-regulation and in collaboration with other organizations 
(Vernis et al., 2004; Becker, 2018). Among the external control initiatives, the Transparency and Good Governance indicators developed by the Spanish Development NGO Coordinator (CONGDE) ${ }^{3}$ and the Transparency and Good Practices Guide of the Lealtad Foundation ${ }^{4}$ stand out. These efforts related to self-regulation encourage good governance in NGOs by offering a set of good practices related to adequate organization; effectiveness, efficient, and ethically correct functioning (Medina, 2009); responsible actions; and transparency in the use of funds (Fuentes, 2007).

Spain's NGOs have also increased their use of internal control mechanisms. Specifically, despite the lack of law or regulation dictating disclosure, NGOs commonly provide information on their websites that donors and partners, current or potential, can use to evaluate their donations or membership.

\subsubsection{External control mechanisms}

External certification and accreditation is considered a strong form of voluntary accountability in the nonprofit sector (Gugerty, 2009; Willems et al., 2017) since an independent, external organization reviews the quality of the nonprofits' processes and programs (Slatten et al., 2011).

To improve society's knowledge of NGDOs and to promote transparency as a strategic value of the sector, CONGDE developed the Transparency and Good Governance Tool. This tool is structured as 2 sections in 10 blocks with 79 indicators (CONGDE, 2015) that help to paint a picture of the NGDO including how the work is carried out, what the internal processes are, the decision-making process, the obtained results, how well responsibilities are defined, whether continuous improvement is promoted, the presence (or absence) of adequate planning mechanisms, and indicators of control and accountability. After two years of plan implementation, all participating organizations must submit to an evaluation, conducted by an external auditor registered in the Official Register of Account Auditors. The audit verifies whether the NGDO is in compliance with all indicators of transparency and good governance and then issues a report. The CONGDE, after reviewing and evaluating the report, determines whether to grant the NGDO the "seal of transparency and good governance." The results of the analysis are then made public.

Lealtad Foundation extends the Transparency and Good Practices Guide to address social, humanitarian, and environmental action and development cooperation to improve NGOs' transparency and, consequently, increase society's knowledge of and trust in the sector. The Lealtad Foundation

3.- Founded in 1986, the Spanish Development NGO Coordinator is the main platform of its kind within sectors such as development cooperation, international solidarity, international aid, education for global citizenship and human rights. Transparency and Good Governance Tool is a pioneering initiative within the sector whose application has been obligatory for all the organizations since 2012 (CONGDE, 2015).

4.- Lealtad Foundation's mission is to promote trust in the NGO sector amongst donors and Spanish society in order to increase donations and other types of collaborations. Lealtad Foundation has developed the first NGO monitoring methodology in Spain that is based on a series of standards of transparency and best practices. Since 2001, the foundation has monitored more than 1,000 NGOs, inspiring similar initiatives in Spain and Latin America to work towards increasing charities' accountability. Moreover, Spanish donors have recognized the importance of Lealtad Foundation as a source of public information (Fundación Lealtad, 2015). 
assesses the level of transparency of each NGO based on compliance with 9 principles and 43 indicators on transparency and management (Fundación Lealtad, 2015) related to questions such as the organization's origin, the people behind the organization, how its governing board works, what monitoring systems of the projects are in place, the communication and information channels among collaborators, how it is financed and how it controls the spending of the funds, whether its legal obligations are up to date, and whether it promotes volunteering. NGOs that confirm compliance with these principles and indicators receive the "NGO certified by Lealtad Foundation" seal. The Lealtad Foundation publishes the reports on its web site.

\subsubsection{Internal control mechanisms}

Improving the image of NGOs as agents that serve society (Taylor and Warburton, 2003; Christensen and Mohr, 2003) requires that the organizations disseminate information that responds to issues of importance to interested parties (Gandía, 2011; Cabedo et al., 2017). However, the lack of regulation on the content and format of the information that nonprofit organizations must disclose, together with the sector's reluctance due to the costs associated with increased transparency, have hindered the development of homogeneous standards that facilitate the comparison.

However, the Internet provides NGOs with an opportunity to improve their transparency at a low cost. Web sites, which are highly flexible and accessible, are a strategic element for the transmission of information (Lee et al. al., 2001; Naudé, Froneman, and Atwood, 2004; Ingenhoff and Koelling, 2009; Ozcelik, 2008). They allow stakeholders to access a broad array of constantly updated information in real time (Hoefer and Twis, 2018; López et al., 2019). Consequently, effective use of web sites not only increases transparency but also favors the development and improvement of relationships between donors, volunteers, clients and the community served by the NGO (Hart, 2002; Tremblay-Boire and Prakash, 2015; Hoefer and Twis, 2018). Most NGOs maintain a web site (Hart, 2002). However, NGOs commonly disclose a limited amount of information on their web sites, and their use as a means of communicating relevant information is far from reaching its full potential (Kang and Norton, 2004; Cramer, 2009; Kirk and Abrahams, 2017).

The type of information that NGOs communicate on their web sites tends to be financial and results oriented (Brinkerhoff, 2001). They prioritize the demands of donors because they are sensitive to financial and objective outcomes, and their donations are positively related to the amount of this information disclosed (Gandía, 2011). As a result, the information that NGOs provide does not necessarily correspond to the information demanded by all its stakeholders, and it can be concluded that traditional financial information is no longer sufficient (Saraite et al., 2020). NGOs do a poor job of providing information on its activities carried, its adherence to good governance practices (Vaccaro and Madsen, 2009), and the management and fulfillment of its objectives (Fuentes, 2007). To be useful for all stakeholders, the organization should provide not only financial and objective-related information but also information related to its economic, social, organizational, environmental, and internal functioning (Farwell, Shies and Handy, 2019; Montesinos and Bruna, 2019). 


\section{Methodology}

\subsection{Sample and process of information gathering}

The analysis has been based on the information provided on the website of 114 NGDOs that had been certified either by the CONGDE or by the Lealtad Foundation in 2013. We carried out a web content analysis during the spring of 2014 to obtain the required information to assess online transparency. Information related to organizational variables and data required to gauge efficiency were sourced from the 2014 annual report of each sample organization.

Of the 87 NGDOs that make up CONGDE, 81 had been certified. The Lealtad Foundation certified 181 NGOs, from which we select 61 that work in the field of development cooperation and humanitarian aid. We eliminated one NGDO (OSPAAAL Solidarity) because it lacked a web page, which reduced the sample to 114 NGDOs: 80 certified by CONGDE and 61 certified by Lealtad Foundation, with 27 certified by both.

\subsection{Variables}

\subsubsection{Transparency measure}

The efforts to self-regulate within the NGO sector (e.g., CONGDE, the Lealtad Foundation) provide information that any stakeholder can demand. Thus, a good approximation of an NGO's transparency is to analyze the extent to which its web site provides details related to its organizational and operational function and governance, its activities, and other economic and financial information.

Studies based on web content analysis have been widely used to analyze the amount of information reported by nonprofit organizations (Gálvez et al., 2012; Martín and Martín, 2017b; Andrades et al., 2019; Benito et al., 2019; Pina and Torres, 2019). They use a multi-item instrument from a global index of information disclosure as well as partial indexes according to the type of transparency to be evaluated. Sanz and Koc (2006) develop an index composed of 19 items to determine the availability of information related to vision and strategy, profile of the organization, governance structure, and accounting/financial information. Building on Kang and Norton (2004), Goatman and Lewis (2007), Waters (2007) and the recommendations of CONGDE, Gandía (2011) develops a model composed of 78 items to assess the Internet transparency of the Spanish NGDOs based on four indices: general 
information, financial and government information, navigation and presentation, and interactivity of the Web.

Focusing on the online transparency of American foundations, Saxton and Guo (2011) develop two indexes: financial disclosure consisting of seven items (e.g., annual report, audited financial statements) and disclosure of performance consisting of eight items (e.g., donations received, projects financed). Building on Saxton and Guo (2011), Verbruggen et al. (2011), and the nine principles of transparency of the Lealtad Foundation, Gálvez et al. (2012) develop 29-item index of transparency for Spanish NGOs.

In order to identify the use of web pages as a mechanism for proactive transparency, an online transparency index (TI) has been developed, following recent studies (Gallego-Álvarez et al., 2011; Cuadrado-Ballesteros et al., 2014, Martín and Martin, 2017b; Pina and Torres, 2019; Benito et al., 2019).

We use the scale developed by Gálvez et al. (2012) because it includes the information that the empirical literature considers necessary for an organization to be transparent and it fits the principles of transparency of both the Lealtad Foundation and CONGDE. Table 1 provides Gálvez et al.'s index.

Table 1. The scale for measuring the online transparency

\begin{tabular}{|l|c|c|}
\hline & Max. & Min. \\
\hline 1. Online organizational transparency & 4.0 & 0 \\
\hline a. It provides information on the website about: & 1 & 0 \\
\hline a.1. Number of annual meetings of the governing board & 0.33 & 0 \\
\hline a.2. Topics and issues discussed at the annual meetings of the board & 0.33 & 0 \\
\hline a.3. Agreements adopted by the governing board & 0.33 & 0 \\
\hline b. Information about the members of the board: & 1 & 0 \\
\hline b.1. Are the names of the members of the board and management team public? & 0.2 & 0 \\
\hline b.2. Are the professions or public positions of the members of the board public? & 0.2 & 0 \\
\hline b.3. Are family relations and relationships with members of the board and with the manage- \\
ment team public? & 0.2 & 0 \\
\hline b.4. Are management team curriculum vitae public? & 0.2 & 0 \\
\hline b.5. Are the relationships among the members of the board and suppliers and activity co-or- \\
ganizers public? & 0.2 & 0 \\
\hline c. Is the renewal of the board members public? & 1 & 0 \\
\hline d. Is the policy to avoid conflicts of interest among the members of the board public? & 1 & 0 \\
\hline 2. Online activities transparency & 8 & 0 \\
\hline a. Is the social goal public? & 1 & 0 \\
\hline
\end{tabular}




\begin{tabular}{|c|c|c|}
\hline $\begin{array}{l}\text { b. Is the information provided of the social goal clear and according to the activity performed and } \\
\text { beneficiaries? }\end{array}$ & 1 & 0 \\
\hline c. Is the strategic plan public? & 1 & 0 \\
\hline d. Is the annual plan public? & 1 & 0 \\
\hline e. Are the reports of monitoring and justifying projects public? & 1 & 0 \\
\hline f. Are the criteria and process of selecting project and counterparts approved by the board public? & 1 & 0 \\
\hline g. Is the activities annual report public? & 1 & 0 \\
\hline h. Is the information about the activities that volunteers can perform public? & 1 & 0 \\
\hline 3. Online economic transparency & 17 & 0 \\
\hline 3.1. Financial information transparency & 6 & 0 \\
\hline a. Is the annual cost of private and public fundraising public? & 1 & 0 \\
\hline b. Is the annual fundraising public? & 1 & 0 \\
\hline $\begin{array}{l}\text { c. Is the information about fundraising of the main funders, both public and private, and the } \\
\text { amounts contributed by them public? }\end{array}$ & 1 & 0 \\
\hline d. Is the allocation of funds raised in each activity public? & 1 & 0 \\
\hline e. Is the privacy policy of members and donors public? & 1 & 0 \\
\hline f. Is the information about the clauses of licensing logo to companies and institutions public? & 1 & 0 \\
\hline 3.2. Transparency in the use of financial resources & 11 & 0 \\
\hline $\begin{array}{l}\text { a. Is the operating cost grouped in three categories: fundraising, programmes-activities, adminis- } \\
\text { tration-organizers, public? }\end{array}$ & 1 & 0 \\
\hline b. Is the information about the fund applied by each project and area of work public? & 1 & 0 \\
\hline c. Are the names of the main suppliers public? & 1 & 0 \\
\hline d. Are the entities that participate in NGO's activities organization public? & 1 & 0 \\
\hline e. Is the approval expenses policy public? & 1 & 0 \\
\hline f. Are suppliers selections' criteria approved by the governing board public? & 1 & 0 \\
\hline g. Is the annual budget of the following year with an explanatory report public? & 1 & 0 \\
\hline h. Is the annual budget of the previous year public? & 1 & 0 \\
\hline i. Does any information about the tracking system of donors' funds on the website? & 1 & 0 \\
\hline j. Is the economic annual report public? & 1 & 0 \\
\hline k. Is the audit report public? & 1 & 0 \\
\hline
\end{tabular}

SOURCE: Gálvez et al. (2012).

Using Gálvez et al.'s (2012) index (see Table 1), we examine each NDGO in our sample to determine whether it makes the information corresponding to each item publicly available on its website. We form each item in the index as a dummy variable that equals 1 if the information is available on the 
website, and zero otherwise, in line with Bonsón and Escobar (2006). All observations therefore have equal weight. After we obtain values for each of the 29 items (it $\mathrm{i}_{\mathrm{j}}$, we form an online information disclosure index (IDI) for each organization, following recent studies (Gallego-Álvarez et al., 2011; Cuadrado-Ballesteros et al., 2014; Martín and Martin, 2017b; Pina and Torres, 2019; Benito et al., 2019), calculated as a percentage based on the sum of the points relative to the maximum points possible:

$$
I D I=\frac{\sum_{j=1}^{n} i t_{j}}{n} \times 100
$$

Because Gálvez et al. (2012) divide their index based on organizational, activities, and economic aspects, we disaggregate the index into three subindexes: organizational transparency (IDI $)$, calculated from the first four items; the transparency of activities $\left(\operatorname{IDI}_{A}\right)$, calculated from the following eight items; and economic transparency (IDI $\mathrm{E}_{\mathrm{E}}$ ), calculated from the last 17 items. Similar to the full index, we calculate each subindex as a percentage based on the sum of the points relative to the maximum points:

$$
I D I=I D I_{O}+I D I_{A}+I D I_{E}=\left(\frac{\sum_{j=1}^{4} i t_{j}}{4}+\frac{\sum_{j=5}^{12} i t_{j}}{8}+\frac{\sum_{j=13}^{29} i t_{j}}{17}\right) \times \frac{100}{3}
$$

The question arises of whether we should weight the subindexes or give each subindex the same weight. In line with Gálvez et al. (2012), Cuadrado-Ballesteros et al. (2014), Martín and Martín (2017b) and Benito et al. (2019) we do not establish any weighting. Choi (1973), Robbins and Austin (1986), and Chow and Wong-Boren (1987) show that results are similar using weighted indices or unweighted indices. Thus, we avoid the subjectivity required to apply weights (Dhaliwal, 1980) by using an equally weighted index.

\subsubsection{Efficiency measure}

DEA, developed by Charnes et al. (1978), is a linear programming technique that allows the evaluation of the relative efficiency of different units. DEA methodology is especially suited for the nonprofit sector because it allows us to adapt for the unique characteristics of NGOs, such as difficulty in determining the price of the products or services they generate, the production function to which they adjust, and the presence of multiple inputs and outputs. Efficiency calculates by means of DEA allows to measure the degree to which nonprofits are able to turn inputs (what they spend) into outputs, the goods and services produced for community (Coupet and Berret, 2019). This method allows us to establish an objective measure of efficiency for groups of organizations that do not have aggregate indicators and multiple simultaneous objectives (Marcuello, 1999; Martín et al., 2007; Martín and Martín, 2017a; Hernangómez et al., 2009; García and Marcuello, 2007; Golden et al., 2012; Martín et al., 2012). This measure based on objective data help prevent the risk of desirability bias inherent to self-reported performance assessments in nonprofits (Rey, Sanzo and Álvarez, 2018). 
DEA requires that we determine the relevant outputs and inputs to measure efficiency. Prior studies have applied DEA to the international development cooperation sector to approximate outputs such as project expenses (Marcuello, 1999; Golden et al., 2012), income volume (García and Marcuello, 2007), and the number of projects (Hernangómez et al., 2009; Martín et al., 2007) and inputs such as operating expenses, donations (Marcuello, 1999; Golden et al., 2012), grants (Marcuello, 1999); number of volunteers (Marcuello, 1999; García y Marcuello, 2007), administration expenses (García and Marcuello, 2007; Golden et al., 2012), income volume (García and Marcuello, 2007; Hernangómez et al., 2009; Martín et al., 2007; Golden et al., 2012), number of employees (García and Marcuello, 2007; Hernangómez et al., 2009; Martín et al., 2007), and organizational age (Hernangómez et al., 2009; Martín et al., 2007). Some parameters are considered as both inputs and outputs due to the two-stage structure of NGDO's operation: (a) actions aimed at attracting funds and (b) the application of obtained resources to execute projects. Based on a review of the literature, we find that the most relevant outputs are projects expenses and the number of executed projects and the most relevant inputs are total income and number of workers hired.

\subsubsection{Control variables}

We consider several control variables that the empirical literature considers influential on efficiency: organization age (Andrés et al., 2006, 2010; García and Marcuello, 2007; Rocha et al., 2015), legal form (Marcuello, 1999; García and Marcuello, 2007; Andrés et al., 2006, 2010), size of the governing board (Andrés et al., 2006, 2010), number of volunteers (Andrés et al., 2006; García y Marcuello, 2007), and the public revenues obtained (Andrés et al., 2006; García and Marcuello, 2007).

We measure organization age (Age) as the number of years the organization has been in operation (i.e., difference between the year of data collection of the sample and the year in which the organization was created). We measure the legal form (Legal) of the organization with a dichotomous variable that equals 1 when the legal form is a foundation, and zero otherwise. The size of the governing board (Gov_Board) is the number of components that make up the board (foundation) or the board of directors (association). Public revenues (Pub_Rev) are the percentage of public funds relative to the NGDO's total income. The number of volunteers (Volunt) is the total number of volunteers who collaborate with the organization.

\subsection{Empirical Analysis}

Firstly, we calculate the online transparency index using the scale of Gálvez et al. (2012) as it was explained in the previous sections. Secondly, we determine the efficiency of each NGDO in our sample by applying DEA. This method identifies the efficient units and builds a frontier formed by the linear combinations between those units. The efficiency of the other units is measured according to their distance from the calculated efficient frontier. 
The formalization of the analysis results in a mathematical optimization model whose estimated variables are the efficiency indices, defined as the quotient between the weighted sums of the outputs and the weighted sums of the inputs. This nonparametric technique does not specify a concrete functional form between the maximum of achievable outputs and the required inputs. This method provides a measure of efficiency for each organization, scored as a value between zero and 1, where 1 corresponds to the location on the efficient frontier. The model also determines the weightings that endogenously correspond to the values of greater possible efficiency.

Before continuing, we consider the proper orientation of the analysis (output or input). Given an output orientation, a unit is efficient if no other unit can produce a higher level of outputs with the same level of inputs. Given an input orientation, a unit is efficient if no other unit that, by decreasing the number of inputs (maintaining the proportion), obtains the same quantity of outputs. We determine that an input orientation is better adapted to our study due to the way that NGDOs define their objectives to realize their projects with the least possible resources.

Finally, to assess the influence of online transparency on efficiency, we use an ordinary least squares regression, where the dependent variable is the efficiency level of each organization, as calculated by $D E A$, and the independent variables are the online information disclosure index along with the control variables. The model is estimated as

$$
\text { Efficiency }=\beta_{0}+\beta_{1} \text { Age }+\beta_{2} \text { Legal }+\beta_{3} \text { Gov_Board }+\beta_{4} \text { Volunt }+\beta_{5} \text { Pub_Rev }+\beta_{6}|D|+\mu
$$

\section{Results}

Table 2 shows that the online transparency of Spanish NGDOs is not particularly high, given that the global index (IDI) for the sample is $53.2 \%$. In other words, NGDOs holding a seal of approval for transparency from CONGDE and/or the Lealtad Foundation only make public on their websites roughly one half of the information considered relevant for adequate accountability. However, important differences exist depending on the type of information considered. The activity transparency subindex $\left(\mathrm{IDI}_{\mathrm{A}}\right)$ has the highest value at almost $65 \%$ whereas the economic transparency subindex (IDI $\mathrm{E}_{\mathrm{E}}$ ) has the worst score of just $43 \%$. The organizational transparency subindex $\left(\mathrm{IDI}_{\mathrm{O}}\right)$ is $52.3 \%$, very similar to the global transparency index. 


\section{Table 2. Results of online transparency}

\begin{tabular}{l|c}
\multicolumn{1}{c|}{ Disclosure index (IDI } & Average (\%) \\
\hline 1.Online Organizational Transparency (IDI $)$ & 52.3 \\
\hline 2. Online Activities Transparency $\left(\mathrm{IDI}_{\mathrm{A}}\right)$ & 64.8 \\
\hline 3. Online Economic Transparency $\left(\mathrm{IDI}_{\mathrm{E}}\right)$ & 42.60 \\
\hline 3.1. Financial information transparency & 44.90 \\
\hline 3.2. Transparency in the use of financial resources & 37.3 \\
\hline Total Disclosure Index (IDI) & 53.20 \\
\hline
\end{tabular}

SOURCE: Prepared by authors based on information contained on the website of each NGDO.

Considering the online organizational transparency subindex (IDI $)$, more than $90 \%$ of the sample NGDOs provides information and professional profiles for members of the governing boards. However, few organizations provide information on kinship or affinity relations for either members of the governing board or for providers and co-organizers. The lack of transparency in this area may be due to the effort required to update these relationships, especially given that they are under no legal obligation to do so.

The online activity transparency subindex $\left(I D I_{A}\right)$ offers the best results. All but one sample NDGOs clearly report their social purpose, their field of activity, and the population they serve. Because this basic information, which positions and differentiates the organization in its field, is static and does not require updating, it is easily maintained on the web site. Although $90 \%$ of the sample NGDOs provides an annual activity report on their websites, only $8 \%$ make public their annual plan. This finding raising the question: Do NGDOs operate proactively in line with a systematic and deliberate plan of action, or do they operate reactively, in response to the priorities set by donors at each moment of time.

The economic transparency subindex $\left(\left.I D\right|_{E}\right)$ has an overall value of $42.6 \%$. The first block, which corresponds to transparency in financing, has an average value of $44.9 \%$, whereas the second block, which corresponds to transparency in the use of financial resources, has an average value of $37.3 \%$. These values are substantially lower than expected, given that nonprofit organizations disclose information primarily to their donors and sponsors informed. Thus, donors and sponsors would logically push NGDOs to provide information related to the source and distribution of funds.

The index score for the disclosure of information relative to annual fundraising efforts is $78 \%$. Almost all organizations include this information in their annual reports, which are commonly accessible on their websites. However, only $30 \%$ of NGDOs make publicly available information related to the cost of fundraising, which is legally required. This low score is perhaps motivated by NGDOs' fear that 
sponsors and donors will react negatively to the information that a portion of their resources does not directly fund the organizations' projects and purposes. Finally, only $12 \%$ of the NGDOs report information related to any logo transfer clauses with companies or public organizations with which they are associated.

Regarding transparency related to use of funds, $79 \%$ of the sample NGDOs publish their annual financial statements online. This score reflects the importance that the organizations attach to showing clear financial accountability. In fact, $76 \%$ make publicly available the audit report, which verifies that the financial statements are in line with accounting principles and are a true reflection of the organization's assets. However, other fundamental details are missing: Only $2 \%$ to $6 \%$ of NGDOs provide data on such topics as the policy of approval of expenses, suppliers selection criteria, identification of the main suppliers, or preparation of the budget for the following year.

Table 3 provides the estimation of efficiency. The sample NGDOs are substantial in size. On average, they manage revenues of more than 23 million euros (US\$26.4 million) and have an average staff of 262 employees. They develop an average of 103 projects per year, incurring direct project costs of more than 19 million euros (US $\$ 21.8$ million; approximately $83 \%$ of overall income). The DEA, using an input orientation, shows that the average efficiency of sample NGDOs is 0.81 , where 1 is the maximum possible. This value is significantly high compared with the average efficiency of the development cooperation sector, as found by previous empirical studies (Marcuello, 1999; Hernangómez et al., 2009; Golden et al., 2012). In addition, the median is 0.91 (SD =0.22). This result indicates that not only the average efficiency is high but also that most individual NGDOs in the sample achieve high efficiency values.

\section{Table 3. Average of efficiency and variables used in data envelopment analysis}

\begin{tabular}{lc}
\hline Variables & Average Value \\
\hline Outputs & \\
Project expenses (euros) & $19,114,898$ \\
Number of executed projects & 103 \\
Inputs & $23,099,828$ \\
Total income (euros) & 262 \\
Number of employees & 0.81 \\
\hline Efficiency & \\
\hline
\end{tabular}

SOURCE: Prepared by authors. 
After estimating the efficiency and determining the online transparency of the sample organizations, we analyze the influence of online transparency on efficiency, using previously proposed model. Regarding the validity of the model, the value of the F-ratio allows us to reject the hypothesis of independent variables coefficients joint nullity; it explains a reasonable percentage (24\%) of the variance of the efficiency, and the coefficients of the variables are, in general, in line with previous literature. Concerning the multicollinearity between the independent variables, all the tests indicate no multicollinearity exists. Table 4 shows that the correlation coefficients of the variables are not high. The inflation factors of the variance do not exceed the value 2, far from the critical value of 10 (Gujarati, 2003; Hair et al., 2001), and the condition indices, whose maximum value is 11, are much lower than the limit value of 30 (Gujarati, 2003; Hair et al., 2001; Pindyck and Rubinfeld, 2000; Greene, 1998). The value of the Durbin-Watson statistic is 2.11; due to its relative proximity to 2, this result does not indicate serious noncompliance with the basic autocorrelation hypothesis. Based on these considerations, we determine that the model has an acceptable explanatory capacity and meets the statistical requirements reasonably well.

\section{Table 4. Pearson correlation coefficients}

\begin{tabular}{|c|c|c|c|c|c|c|c|}
\hline & Age & Legal & Gov_Board & Volunt. & Pub_Rev & IDI & Efficiency \\
\hline Age & 1 & & & & & & \\
\hline Legal & $-0.254^{\star \star *}$ & 1 & & & & & \\
\hline Gov_Board & $0.363^{\star \star \star}$ & 0.27 & 1 & & & & \\
\hline Volunt. & $0.646^{\star \star \star}$ & -0.137 & $0.487^{\star \star *}$ & 1 & & & \\
\hline Pub_Rev & -0.054 & -0.062 & -0.070 & $-0.192^{\star *}$ & 1 & & \\
\hline IDI & 0.000 & $-0.200^{* *}$ & 0.158 & 0.009 & $0.168^{* *}$ & 1 & \\
\hline Efficiency & -0.152 & 0.027 & -0.138 & $-0.290^{\star \star \star}$ & $0.352^{\star \star *}$ & $0.301^{\star * *}$ & 1 \\
\hline \multicolumn{8}{|c|}{ Notes: ${ }^{* \star}$ and ${ }^{* *}$ denote two-tailed significance at the 0.01 and 0.05 levels, respectively. } \\
\hline \multicolumn{8}{|c|}{$\begin{array}{l}\text { Age: Organization age. Legal: Legal form of the organization. Gov_Board: Size of the governing board. Volunt: Number of volun- } \\
\text { teers. Pub_Rev: Percentage of public funds. IDI: Online information disclosure index. Efficiency: Level of efficiency of each organi- } \\
\text { zation }\end{array}$} \\
\hline
\end{tabular}

SOURCE: Prepared by authors.

Table 5 shows that online transparency (IDI) has a positive and significant influence on the level of efficiency, supporting our hypothesis that a greater disclosure of information is positively related to efficiency. Increased stakeholders' knowledge and ability to make comparisons motivates NGDOs to be more efficient to generate trust and therefore continued support from funders in particular and society in general. Loss of trust due to lack of transparency may jeopardize the organizations' sustainability in the medium and long term. 
Table 5. Relation between online transparency and efficiency

\begin{tabular}{|l|c|c|}
\hline Variables & Coefficient & Standard error \\
\hline Constant & $0.508^{* * *}$ & 0.083 \\
\hline Age & 0.063 & 0.001 \\
\hline Legal & 0.087 & 0.041 \\
\hline Gov_Board & -0.076 & 0.003 \\
\hline Volunt & $-0.234^{*}$ & 0.000 \\
\hline Pub_Rev & $0.262^{* *}$ & 0.061 \\
\hline IDI & $0.289^{* * *}$ & 0.001 \\
\hline \multicolumn{2}{|c|}{0.278} \\
\hline$R^{2}$ & 0.234 & \\
\hline Adj. $R^{2}$ & $6.293^{* * *}$ \\
\hline F & 2.110 & \\
\hline Durbin-Watson & \multicolumn{1}{|c|}{} \\
\hline $\begin{array}{l}\text { Notes: }{ }^{* * *},{ }^{* *}, \text { and }{ }^{*} \text { denote significance at the } 0.01,0.05, \text { and } 0.10 \text { levels, respectively. } \\
\text { Age: Organization age. Legal: Legal form of the organization. Gov_Board: Size of the governing board. Volunt: Number of } \\
\text { volunteers. Pub_Rev: Percentage of public funds. IDI: Online information disclosure index. }\end{array}$ \\
\hline
\end{tabular}

SOURCE: Prepared by authors.

Regarding the control variables, the age of the organization, used as an approximation of experience, accumulated know-how, and reputation, has a positive effect on efficiency, in line with prior literature (Andrés et al., 2006, 2010; Rocha et al., 2015), but the effect is not statistically significant. Regarding the legal form of the organization, foundation has a positive but not statistically significant effect on efficiency. Board size has a negative but not statistically significant effect on efficiency. This finding is in line with prior literature that suggests larger government boards make communication, coordination, and decision-making more difficult and therefore increase costs and damages efficiency (Callen, Klein, and Tinkelman, 2003; Regan and Oster, 2005; Andrés et al., 2006).

The number of volunteers has a negative and significant influence on efficiency. This result is contrary to our expectations because volunteers contribute non-compensated working hours, which should allow the organization to develop more activities without hiring employees and increasing operating expenses. This result may be explained by the complexity of projects undertaken by major NGDOs, which require the advanced skill and knowledge of staff, as demanded by funders, to complete.

Finally, public income as a proportion of total income has a positive and significant influence on efficiency. This finding is in line with previous studies (Herman and Renz, 2000; O'Regan and Oster, 2002; Andrés et al., 2006) that show that the presence of large donors (in this case, large public do- 
nors) favors increased supervision of the organization. These donors have sufficient power to access the relevant information (budgets, planning, reports of each project), and this level of control translates into improved efficiency.

To check the robustness of the results, we estimate the model substituting the global transparency index on the Internet (IDI) for the three transparency subindexes $\left(I D I_{O}, I D I_{A},\left.I D\right|_{E}\right)$, while maintaining the control variables. Table 6 shows the results, which confirm our previous findings, although the explanatory power of the subindex models is lower than that of the model for the full sample. Thus, although the different types of online transparency-organizational, activities related, and economic-have an effect on efficiency, global transparency exerts a greater influence This results suggests that for an organization to improve its efficiency it cannot only disclose more information in a specific area but must increase transparency on all matters related to the organization's functioning.

\section{Table 6. Robustness analysis}

\begin{tabular}{|c|c|c|c|}
\hline Variables & Model 1 & Model 2 & Model 3 \\
\hline Constant & $0.616^{\star \star *}$ & $0.486^{\star \star *}$ & $0.564^{* * *}$ \\
\hline Age & 0.053 & 0.050 & 0.045 \\
\hline Legal & 0.090 & 0.021 & 0.042 \\
\hline Gov_Board & -0.045 & -0.047 & -0.066 \\
\hline Volunt & $-0.250^{\star \star}$ & $-0.251^{\star \star}$ & $-0.200^{*}$ \\
\hline Pub_Rev & $0.252^{* * *}$ & $0.302^{\star \star \star}$ & $0.315^{* \star *}$ \\
\hline$|D|_{0}$ & $0.221^{* *}$ & & \\
\hline$|D|_{A}$ & & $0.230^{* * *}$ & \\
\hline$|D|_{E}$ & & & $0.236^{\star \star \star}$ \\
\hline$R^{2}$ & 0.217 & 0.228 & 0.229 \\
\hline Adj. $R^{2}$ & 0.173 & 0.185 & 0.186 \\
\hline $\mathrm{F}$ & $4.931^{\star * *}$ & $5.267^{\star \star *}$ & $5.294^{\star \star \star}$ \\
\hline Durbin-Watson & 2.259 & 2.400 & 2.258 \\
\hline \multicolumn{4}{|c|}{$\begin{array}{l}\text { Age: Organization age. Legal: Legal form of the organization. Gov_Board: Size of the governing board. Volunt: Number of } \\
\text { volunteers. Pub_Rev: Percentage of public funds. } I D I_{O} \text { : Online organizational transparency subindex. } I D I_{A} \text { : Online activity } \\
\text { transparency subindex. IDI: Online economic transparency subindex. }\end{array}$} \\
\hline
\end{tabular}

SOURCE: Prepared by authors. 


\section{Conclusions, discussion and limitations}

The discovery of abuses and fraud in recent years in some well-known NGOs on the national and international scene has increased concern among donors and other stakeholders about the governance of nonprofit organizations and increased demand for transparency and improved efficiency.

Although external organizations such as the Spanish NGO Coordinator (CONGDE) and the Lealtad Foundation offer NGOs a certification process and a seal of approval for transparency, this process in and of itself is not sufficient. NGOs must go a step further by disclosing the information that, according to these certifications, shows that the organization acts in accordance with a set of good practices, has good governance, and clearly explains the use of funds received and, in addition, this information should be publicly available through easily accessible means.

Web sites are an ideal channel for NGOs to communicate information to donors and other stakeholders. Web sites allow NGOs to provide complete and easily updated information at a low cost, allowing they to devote more of their scarce resources to implementing their goals and projects. Increasing the public's knowledge of what the organization does, how it does it, who benefits, what results are, and how it is being financed reduces the informative asymmetries between organizations and stakeholders. By increasing transparency, NGOs can mitigate the problems of accountability related to the absence of owners in the strict sense (compared to for-profit firms) and thus garner stakeholders' trust and continued support.

This study shows that transparency should be a priority for NGDOs. As such, it should be promoted by the governing body (i.e., board of trustees or board of directors) and integrated into the organization's strategic vision. Improved transparency increases organizations' incentive to improve performance by allowing for comparison between NGOs and promotes greater donor confidence and adds to legitimacy and stability of the organization. Organizations with greater transparency are more exposed to public scrutiny and thus are motivated to make better use of their resources by strengthening their governance structure and applying better management practices. Although transparency imposes costs for the reporting entity, the beneficial effects on efficiency should be considered.

This study shows the need for accurate and reliable efficiency indicators that allow both society in general and donors and taxpayers in particular to discriminate between more and less efficient organizations. A more accurate measurement of efficiency allows stakeholder to establish comparisons when deciding which entity to contribute to. This would result in greater competition in the development 
sector which in turn would motivate NGDOs to strive for continuous improvement. Our use of DEA, which considers multiple dimensions of organizational functioning, provides an enriched vision of the phenomenon. DEA can be extremely useful for managers, because it allows for a more exhaustive analysis of why some organizations are able to use their resources more efficiently. As a result, the sector can establish best practices, based on the highest performing organizations.

Regarding the research limitations, we analyze the transparency-efficiency relationship using cross-sectional data, which do not allow us to demonstrate causality. Future studies should test the causality by means of longitudinal analyses. The application of the DEA requires organizations to be comparable in terms of objectives, activities, factors used, and goods/services produced. Although our sample is composed of NGDOs that, in principle, constitute a fairly homogeneous group within the nonprofit sector, we do not consider the certain level of heterogeneity that exists in the processes of setting objectives, the structure of their objectives, their strategies, and the diversity in the nature of their outputs. Thus, our results should be accepted with caution. Also, we examine Spanish NGDOs; whether our results can be generalized to NGDOs from other countries or to other types of NGOs is unknown. The sample comprises organizations that have been accredited as transparent by external institutions. Thus, we may introduce a bias when trying to extrapolate our results to other organizations without transparency accreditation seals. Finally, content of NGDOs' web pages is the only aspect considered in this study, however, presentation and navigation, the other two basis aspects that ensure Web Quality Model, in line with Calero et al. (2005), could be important because they make information easier to find and use. 


\section{References}

ANDRADES, J., MARTíNEZ-MARTíNEZ, D., LARRÁN, M. \& HERRERA, J. (2019): "Online information disclosure in Spanish municipal-owned enterprises: A study based on the compliance with transparency requirements", Online Information Review, 43(5), 922-944, DOI: 10.1108/OIR-022018-0063.

ANDRÉS-ALONSO, P., MARTíN-CRUZ, N. \& ROMERO-MERINO, M.E. (2006): "The governance of nonprofit organizations: Empirical evidence from nongovernmental development organizations in Spain", Nonprofit and Voluntary Sector Quarterly, 35(4), 588-604, DOI: 10.1177/0899764006289765.

ANDRÉS-ALONSO, P., AZOFRA-PALENZUELA, V. \& ROMERO-MERINO, M.E. (2010): "The governance of nonprofit organizations: Empirical evidence from nongovernmental development organizations in Spain", British Journal of Management, 21(4), 100-114, DOI: 10.1177/0899764006289765.

BANERJEE, A.V. (2009): "Big answers for big questions: The presumption of growth policy". In J. Cohen \& W. Easterly (Eds.), What works in development? Thinking big and thinking small, Washington: The Brooking Institution, 207-221, DOI: 10.7864/j.ctt6wpghn

BECKER, A. (2018): "An experimental study of voluntary nonprofit accountability and effects on public trust, reputation, perceived quality, and donation behavior", Nonprofit and Voluntary Sector Quarterly, 47(3), 562-582, DOI: 10.1177/0899764018756200.

BENITO-ESTEBAN, C.I., GARCÍA-RODRÍGUEZ, I. \& ROMERO-MERINO, E. (2019): "Towards a higher transparency. The use of websites by NGDOs", UCJC Business \& Society Review (formerly known as Universia Business Review), 16(3), 18-71, DOI: 10.3232/UBR.2019.V16.N3.01.

BENJAMIN, L.M. (2010): "Funders as principal. Performance measurement in philanthropic relationships", Nonprofit Management and Leadership, 20(4), 383-403, DOI: 10.1002/nml.20001.

BIES, A.L. (2010): "Evolution of nonprofit self-regulation in Europe", Nonprofit and Voluntary Sector Quarterly, 39(6), 1057-1086, DOI: 10.1177/0899764010371852.

BONSÓN, E. \& ESCOBAR, T. (2006): "Online transparency of the banking sector", Online Information Review, 30(6), 714-730, DOI: 10.1108/14684520610716180.

BRINKERHOFF, D.W. (2001): Taking account of accountability: A conceptual overview and strategic options, Washington, DC: U.S. Agency for International Development, Center for Democracy and Governance. 
BURGER, R. \& OWENS, T. (2010): "Promoting transparency in the NGO sector", World Development, 38(9), 1263-1277, DOI: 10.1016/j.worlddev.2009.12.018.

CABEDO, J.D., FUERTES-FUERTES, I., MASET-LLAUDES, A. \& TIRADO-BELTRÁN, J.M. (2017): "Improving and measuring transparency in NGOs: A disclosure index for activities and projects", Nonprofit Management and Leadership, 28(3), 383-403, DOI: 10.1002/nml.21298.

CALERO, C., RUIZ, J. \& PIATTINI, M. (2005): "Classifying web metrics using the web quality model", Online Information Review, 29(3), 227-248, DOI: 10.1108/14684520510607560.

CALLEN, J.L., KLEIN, A. \& TINKELMAN, D. (2003): "Board composition, committees and organizational efficiency: The case of nonprofits", Nonprofit and Voluntary Sector Quarterly, 32(4), 493-520, DOI: $10.1177 / 0899764003257462$.

CARVALHO, A.O., RODRIGUES, L.L. \& BRANCO, M.C. (2017): "Factors influencing voluntary disclosure in the annual reports of Portuguese foundations", Voluntas, 28(5), 2278-2311, DOI: 10.1007/ s11266-017-9883-8.

CHARNES, A., COOPER, W. \& RHODES, E. (1978): "Measuring the efficiency of decisions making units", European Journal of Operational Research, 2(6), 429-444, DOI: 10.1016/03772217(78)90138-8.

CHOI, F.D.S. (1973): "Financial disclosure and entry to the European capital market", Journal of Accounting Research, 11(2), 159-175, DOI: 10.2307/249018710.2307/2490187.

CHOW, C.W. \& WONG-BOREN, A. (1987): "Voluntary financial disclosure by Mexican corporations", Accounting Review, 62(3), 533-541.

CHRISTENSEN, R.A. \& EBRAHIM, A. (2006): "How does accountability affect mission? The case of a nonprofit serving immigrants and refugees", Nonprofit Management and Leadership, 17(2), 195209, DOI: 10.1002/nml.143.

CHRISTENSEN, A. \& MOHR, R.M. (2003): "Not-for-profit annual reports: What do museum managers communicate?", Financial Accountability and Management, 19(2), 139-158, DOI: 10.1111/14680408.00167 .

CHRISTENSEN, Z., NIELSEN, R., NIELSON, D. \& TIERNEY, M. (2011): Transparency squared: The effects of donor transparency on aid recipients' corruption levels, paper presented at conference International Political Economy Society, November 12-13, Cambridge, Massachussets, available at: http://aiddata.s3.amazonaws.com/TransparencySquared_aiddata.pdf. (accessed 10 July 2015).

CONGDE: Spanish Development NGO Coordinator (2015): Herramienta de transparencia y buen gobierno, available at: https://coordinadoraongd.org/publicaciones/herramienta-de-transparencia-y-buen-gobierno-de-la-coordinadora (Accessed 15 July 2015). 
COUPET, J. \& BERRET, J.L. (2019): "Toward a valid approach to nonprofit efficiency measurement", Nonprofit Management and Leadership, 29(3), 299-320, DOI: 10.1002/nml.21336.

CRAMER, B. (2009): "Using social media to advance your goals", Nonprofit World, 27(1), 20-21.

CUADRADO-BALLESTEROS, B., FRÍAS-ACEITUNO, J. \& MARTíNEZ-FERRERO, J. (2014): "The role of media pressure on the disclosure of sustainability information by local governments", Online Information Review, 38(1), 114-135, DOI: 10.1108/OIR-12-2012-0232.

DE FRANÇA, J.M.F., DE FIGUEIREDO, J.N. \& LAPA, J.S. (2010): "A DEA methodology to evaluate the impact of information asymmetry on the efficiency of not-for-profit organizations with an application to higher education in Brazil", Annals of Operations Research, 173(1), 39-56, DOI: $10.1007 /$ s10479-009-0536-1.

DHALIWAL, D.S. (1980): "Improving the quality of corporate financial disclosure", Accounting and Business Research, 10(40), 385-391, DOI: 10.1080/00014788.1980.9728763.

DUFLO, E. \& KREMER, M. (2003): Use of randomization in the evaluation of development effectiveness, paper presented at the Conference on Evaluation and Development Effectiveness, July 15-16, Washington DC, available at: https://economics.mit.edu/files/765 (Accessed 20 July 2015).

EBRAHIM, A. (2003): "Accountability in practice: Mechanisms for NGOs", World Development, 31(5), 813-829, DOI: $10.1016 / S 0305-750 X(03) 00014-7$.

EBRAHIM, A. (2005): "Accountability myopia: Losing sight of organizational learning", Nonprofit and Voluntary Sector Quarterly, 34(1), 56-87, DOI: 10.1177/0899764004269430.

ECKERD, A. \& MOULTON, S. (2011): "Heterogeneous roles and heterogeneous practices: Understanding the adoption and uses of nonprofit performance evaluations", American Journal of Evaluation, 32(1), 98-117, DOI: 10.1177/1098214010381780.

FARWELL, M.M., SHIER, M.L. \& HANDY, F. (2019): "Explaining trust in Canadian charities: The influence of public perceptions of accountability, transparency, familiarity and institutional trust", Voluntas, 30(4), 768-782, DOI: 10.1007/s11266-018-00046-8.

FUENTES, J. (2007): "Las organizaciones no lucrativas: necesidades de los usuarios de la información financiera", Revista Española del Tercer Sector, 6, 91-118.

FUNDACIÓN LEALTAD (2015): Principios de transparencia y buenas prácticas (The standards of transparency and best practices), available at: https://www.fundacionlealtad.org/principios-de-transparencia (Accessed 15 July 2015).

GÁLVEZ-RODRÍGUEZ, M., CABA-PÉREZ, M. \& LÓPEZ-GODOY, M. (2012): "Determining factors in online transparency of NGOs: A Spanish case study", Voluntas, 23(3), 661-683, DOI: 10.1007/ s11266-011-9229-x. 
GÁLVEZ-RODRÍGUEZ, M., CABA-PÉREZ, M. \& LÓPEZ-GODOY, M. (2014): "Drivers for the proactive online disclosure of information in the NGO sector: The Colombian case", Online Information Review, 38(6), 769-787, DOI: 10.1108/OIR-05-2014-0113.

GÁLVEZ-RODRÍGUEZ, M., CABA-PÉREZ, M. \& LÓPEZ-GODOY, M. (2016): "NGOs efficiency and transparency policy: The Colombian case", Innovar Journal, 26(60), 67-82, DOI: 10.15446/innovar.v26n60.55534.

GALLEGO-ÁLVAREZ, I., RODRÍGUEZ-DOMÍNGUEZ, L. \& GARCÍA-SÁNCHEZ, I.M. (2011): "Information disclosed online by Spanish universities: content and explanatory factors", Online Information Review, 35(3), 360-385, DOI: 10.1108/14684521111151423.

GANDÍA, J.L. (2011): "Internet disclosure by nonprofit organizations: Empirical evidence of nongovernmental organizations for development in Spain", Nonprofit and Voluntary Sector Quarterly, 40(1), 57-78, DOI: $10.1177 / 0899764009343782$.

GARCÍA, L. \& MARCUELLO, C. (2007): "Eficiencia y captación de fondos en las organizaciones no gubernamentales para el desarrollo". CIRIEC-España, Revista de Economía Pública, Social y Cooperativa, 58, 221-249.

GOATMAN, A.K. \& LEWIS, B.R. (2007): "Charity E-volution? An evaluation of the attitudes of UK charities towards website adoption and use", International Journal of Nonprofit and Voluntary Sector Marketing, 12(1), 33-46, DOI: 10.1002/nvsm.272.

GOLDEN, L., BROCKETT, P., BETAK, J., SMITH, K. \& COOPER, W. (2012): "Efficiency metrics for nonprofit marketing/fundraising and service provision. A DEA analysis", Journal of Management and Marketing Research, 10(1), 1-25.

GONEDES, N.J. (1978): "Corporate signaling, external accounting, and capital market equilibrium: Evidence on dividends, income, and extraordinary items", Journal of Accounting Research, 16(1), 26-79, DOI: 10.2307/2490411.

GUGERTY, M.K. (2009): "Signaling virtue: Voluntary accountability programs among nonprofit organizations", Policy Sciences, 42(3), 243-273, DOI: 10.1007/s11077-009-9085-3.

GUJARATI, D.N. (2003): Econometría Básica (4th ed.), McGraw-Hill, México.

HAIR, J.F., ANDERSON, R.E., TATHAM, R.L. \& BLACK, W.C. (2001): Análisis Multivariante (5th ed.), Prentice Hall, Madrid.

HART, T.R. (2002): "ePhilanthropy: Using the internet to build support", International Journal of Nonprofit and Voluntary Sector Marketing, 7(4), 353-360, DOI: 10.1002/nvsm.192.

HERMAN, R.D. \& RENZ, D.O. (2000): "Board practices of especially effective and less effective local nonprofit organizations", American Economic Review of Public Administration, 30(2), 146-160, DOI: 10.1177/02750740022064605. 
HERNANGÓMEZ, J., MARTíN, V. \& MARTÍN, N. (2009): "Implicaciones de la organización interna sobre la eficiencia. La aplicación de la teoría de la agencia y la metodología DEA a las ONGD españolas", Cuadernos de Economía y Dirección de la Empresa, 40, 7-49, DOI: 10.1016/S11385758(09)70041-6.

HOEFER, R. \& TWIS, M.K. (2018): "Engagement techniques by human services nonprofits: A research note examining website best practices", Nonprofit Management and Leadership, 29(2), 261-271, DOI: 10.1002/nml.21329.

INGENHOFF, D. \& KOELLING, A.M. (2009): "The potential of web sites as a relationship building tool for charitable fundraising NPOs", Public Relations Review, 35(1), 66-73, DOI: 10.1016/j.pubrev.2008.09.023.

KANG, S. \& NORTON, H.E. (2004): "Nonprofit organizations' use of the World Wide Web: Are they sufficiently fulfilling organizational goals?", Public Relations Review, 30(3), 279-284, DOI: 10.1016/j. pubrev.2004.04.002.

KEATING, E.K. \& FRUMKIN, P. (2003): "Reengineering nonprofit financial accountability: Toward a more reliable foundation for regulation", Public Administration Review, 63(1), 3-15, DOI: 10.1111/1540-6210.00260.

LEE, T.E., CHEN, J.Q. \& ZHANG, R. (2001): "Utilizing the internet as a competitive tool for non-profit organizations", Journal of Computer Information Systems, 41(3), 26-31, DOI: 10.1080/08874417.2001.11647004.

LEE, R.L. \& BLOUIN, M.C. (2017): "Factors affecting web disclosure adoption in the nonprofit sector", Journal of Computer Information Systems, 59(4), 363-372, DOI: 10.1080/08874417.2017.1370988.

LEFTWICH, R.W., WATTS, R.L., ZIMMERMAN, J.L., BURTON, J.C. \& SCHIPPER, K. (1981): "Voluntary corporate disclosure: The case of interim reporting/discussion", Journal of Accounting Research, 19(Suppl), 50-77, DOI: hdl.handle.net/10.2307/2490985.

LÓPEZ-ARCEIZ, F.J., TORRES, L. \& BELLOSTAS, A.J. (2019), "Is online disclosure the key to corporate governance?", Online Information Review, 43(5), 893-921, DOI: 10.1108/OIR-06-2018-0191.

MARCUELLO, C. (1999): "Análisis de la conducta y eficiencia de las organizaciones no gubernamentales para el desarrollo españolas", Información Comercial Española, 778, 181-196.

MARTÍN, N., HERNANGÓMEZ, J. \& MARTíN, V. (2007): "El deleite de la eficiencia", Universia Business Review, 14, 56-67.

MARTíN, N., MARTíN, V. \& GÁMEZ, C. (2012): "La eficiencia y el "misreporting" contable en las ONGD Españolas. Análisis de los proyectos de cooperación internacional para el desarrollo", Academia, Revista Latinoamericana de Administración, 51, 1-14. 
MARTÍN, V. \& MARTíN, N. (2017a): "Efficiency of international cooperation schemata in African countries: A comparative analysis using a data envelopment analysis approach", South African Journal of Economic and Management Science, 20(1), 1-13, DOI: 10.4102/sajems.v20i1.1401.

MARTíN, V. \& MARTíN, N. (2017b): "La web como mecanismo de transparencia de las ONG. Más allá de la certificación", Revista Española del Tercer Sector, 37, 159-190.

MARTíNEZ, M. (2003): La medición de la eficiencia en las instituciones de educación superior, Fundación BBVA, Billbao, España.

MCGANN, J. \& JOHNSTONE, M. (2006): "The power shift and the NGO credibility crisis", The International Journal of Nor for Profit Law, 8(2), 65-77.

MCGEE, R. (2013): "Aid transparency and accountability: Build it and they'll come?", Development Policy Review, 31(1), 107-124, DOl: 10.1111/dpr.12022.

MEDINA REY, J.M. (2009): "Transparencia y buen gobierno en las ONGD”, Revista Española del Tercer Sector, 11, 93-113.

MONTESINOS, V. \& BRUSCA, I. (2019): "Non-financial reporting in the public sector: Alternatives, trends and opportunities", Spanish Accounting Review, 22(2), 122-128, DOI: 10.6018/ rcsar.383071.

MURTAZA, N. (2012): "Putting the lasts first: The case for community-focused and peer-managed NGO accountability mechanisms", Voluntas, 23(1), 109-125, DOI: 10.1007/s11266-011-9181-9.

NAUDÉ, A.M.E., FRONEMAN, J.D. \& ATWOOD, R.A. (2004): "The use of the Internet by ten South African non-governmental organizations. A public relations perspective", Public Relations Review, 30(1), 87-94, DOI: 10.1016/j.pubrev.2003.11.008.

O'DWYER, B. \& UNERMAN, J. (2007): "From functional to social accountability: Transforming the accountability relationship between funders and non-governmental development organisations", Accounting, Auditing \& Accountability Journal, 20(3), 446-471, DOI: 10.1108/09513570710748580.

O'DWYER, B. \& UNERMAN, J. (2008): "The paradox of greater NGO accountability: A case study of amnesty Ireland", Accounting, Organizations and Society, 33(7-8), 801-824, DOI: 10.1016/j. aos.2008.02.002.

O'REGAN, K. \& OSTER, S. (2002): "Does government funding alter nonprofit governance? Evidence from New York City nonprofit contractors", Journal of Policy Analysis and Management, 21(3), 359-379, DOI: 10.1002/pam.10050.

O'REGAN, K. \& OSTER, S. (2005): "Does the structure and composition of the board matter? The case of nonprofit organizations", Journal of Law, Economics and Organization, 21(1), 205-227, DOI: $10.1093 /$ leo/ewio09. 
PATON, R. \& FOOT, J. (2000): "Nonprofit's use of awards to improve and demonstrate performance: Valuable discipline or burdensome formalities?", Voluntas, 11(4), 329-353, DOI: 10.1023/A:1008939322449.

PHILLIPS, S.D. (2013): "Shining a light on charities or looking in the wrong place? Regulation-by-transparency in Canada", Voluntas, 24(3), 881-905, DOI: 10.1007/s11266-013-9374-5.

PINA, V. \& TORRES, L. (2019): "Online transparency and corporate governance in Spanish governmental agencies", Online Information Review, 43(4), 653-675, DOI: 10.1108/OIR-03-2018-0102.

RAMÍREZ, Y., MERINO, E. \& MANZANEQUE, M. (2019): "Examining the intellectual capital web reporting by Spanish universities", Online Information Review, 43(5), 775-798, DOI: 10.1108/OIR02-2018-0048.

REY-GARCÍA, M., SANZO-PÉREZ, M.J. \& ÁLVAREZ-GONZÁLEZ, L.I. (2018): "The role of formal third-party endorsements and informal self-proclaiming signals in nonprofit reputation building", Nonprofit and Voluntary Sector Quarterly, 47(3), 514-536, DOI: 10.1177/0899764017750492.

ROBBINS, W.A. \& AUSTIN, K.R. (1986): "Disclosure quality in governmental financial reports: An assessment of the appropriateness of a compound measure", Journal of Accounting Research, 24(2), 412-421, DOI: $10.2307 / 2491145$.

ROCHA-VALENCIA, L.A., QUEIRUGA, D. \& GONZÁLEZ-BENITO, J. (2015): "Relationship between transparency and efficiency in the allocation of funds in nongovernmental development organizations", Voluntas, 26(6), 2517-2535, DOI: 10.1007/s11266-014-9527-1.

SANTOS, M.R.C., LAUREANO, R.M.S. \& MORO, S. (2020): "Unveiling research trends for organizational reputation in the nonprofit sector", Voluntas, 31(1), 56-70. DOI: 10.1007/s11266-018-000557.

SANZ, C.J. \& KOC, A.C. (2006): "Transparencia de la información en Internet del sector no lucrativo en España", Partida Doble, 183, 96-105.

SANZO-PÉREZ, M.J., REY-GARCÍA, M. \& ÁLVAREZ-GONZÁLEZ, L.I. (2017): "The drivers of voluntary transparency in nonprofits: Professionalization and partnerships with firms as determinants", Voluntas, 28(4), 1595-1621, DOI: 10.1007/s11266-017-9882-9.

SARAITE-SARIENE, L., ALONSO-CAÑAdAS, J., GALÁN-VALDIVIESO, F. \& CABA-PÉREZ, C. (2020): "Non-financial information versus financial as a key to the stakeholder engagement: A higher education perspective", Sustainability, 12(1), 1-19, DOI: 10.3390/su12010331.

SAXTON, G.D. \& GUO, C. (2011): "Accountability online: Understanding the web-based accountability practices of nonprofit organizations", Nonprofit and Voluntary Sector Quarterly, 40(2), 270-295, DOI: $10.1177 / 0899764009341086$. 
SCHMITZ, H.P., RAGGO, P. \& BRUNO-VAN VIJFEIJKEN, T. (2012): "Accountability of transnational NGOs: Aspirations vs. practice", Nonprofit and Voluntary Sector Quarterly, 41(6), 1175-1194, DOI: 10.1177/0899764011431165.

SLATTEN, L.A.D., GUIDRY, B.N. \& AUSTIN, W. (2011): "Accreditation and certification in the non-profit sector: Organizational and economic implications", Organization Management Journal, 8(2), 112-127, DOI: 10.1057/omj.2011.17.

SZPER, R. \& PRAKASH, A. (2011): "Charity watchdogs and the limits of information-based regulation", Voluntas, 22(1), 112-141, DOI: 10.1007/s11266-010-9156-2.

TAYLOR, M. \& WARBURTON, D. (2003): "Legitimacy and the role of UK third sector organizations in the policy process", Voluntas, 14(3), 321-338, DOI: 10.1023/A:1025618720650.

TREMBLAY-BOIRE, J. \& PRAKASH, A. (2015): "Accountability.org: Online disclosures by US nonprofits". Voluntas, 26(2), 693-719, DOI: 10.1007/s11266-014-9452-3.

VACCARO, A. \& MADSEN, P. (2009): "ICT and an NGO: Difficulties in attempting to be extremely transparent", Ethics and Information Technology, 11(3), 221-231, DOI: 10.1007/s10676-009-91803.

VERBRUGGEN, S., CHRISTIAENS, J. \& MILIS, K. (2011): "Can resource dependence and coercive isomorphism explain nonprofit organizations' compliance with reporting standards?", Nonprofit and Voluntary Sector Quarterly, 40(1), 5-32, DOI: 10.1177/0899764009355061.

VERNIS, A., IGLESIAS, M., SANZ, B. \& SAZ, A. (2004): Los retos de las organizaciones no lucrativas. Claves para el fortalecimiento institucional del tercer sector, Ediciones Granica, Barcelona, España.

WATERS, R.D. (2007): "Nonprofit organizations' use of the Internet. A content analysis of communication trends on the Internet sites of the philanthropy 400", Nonprofit Management and Leadership, 18(1), 59-76, DOI: 10.1002/nml.171.

WILLEMS, J., WALDNER, C.J., DERE, Y.I., MATSUO, Y. \& HOGY, K. (2017): "The role of formal third-party endorsements and informal self-proclaiming signals in nonprofit reputation building", Nonprofit and Voluntary Sector Quarterly, 46(5), 1092-1105, DOI: 10.1177/0899764017720770. 
